\title{
Antiinfluenza Virus Effect of Extracts from Marine Algae and Invertebrates
}

Julia Serkedjievaa,*, Monika Konaklieva ${ }^{\mathrm{b}}$, Stefka Dimitrova-Konaklieva ${ }^{\mathrm{c}}$, Veneta Ivanova $^{\mathrm{a}}$, Kamen Stefanov ${ }^{\mathrm{b}}$, and Simeon Popov ${ }^{\mathrm{b}}$

${ }^{a}$ Institute of Microbiology, Bulgarian Academy of Sciences, Acad. Georgy Bonchev str., bl. 26, 1113 Sofia, Bulgaria. Fax: (359 2) 7001 09. E-mail: viroljul@bas.bg

b Institute of Organic Chemistry with Center of Phytochemistry, Bulgarian Academy of Sciences, Sofia, Bulgaria

c Faculty of Pharmacy, Medical University, Sofia, Bulgaria

* Author for correspondence and reprint requests

Z. Naturforsch. 55c, 87-93 (2000); received July 13/September 21, 1999

Marine Algae, Marine Invertebrates, Influenza Virus, Inhibition

Sixty products, derived from marine organisms, typical of the Bulgarian Black Sea coast, were examined for inhibitory activity on the reproduction of influenza viruses in tissue cultures. The antiviral effect was investigated by the reduction of virus infectivity. Using representative strains of influenza virus it was shown that apparently the inhibitory effect was strain-specific. The most effective products were further studied in fertile hen's eggs and in experimental influenza infection in white mice.

\section{Introduction}

Marine organisms represent a promising source of antiviral compounds (Cannell, 1993; Che, 1991). The inhibitory effect on a range of viruses has been studied (Ballesteros et al., 1992; Ehresmann et al., 1977; Hayashi et al., 1993; Premanathan et al., 1994; Witvrouw and De Clercq, 1997). A limited number of studies have been performed with influenza viruses (Gerber et al., 1958; Ivanova et al., 1991, 1994; Kathan, 1965).

The objective of our study was to investigate a number of marine plants and organisms, typical of the Bulgarian Black Sea coast and to evaluate their potential as a source of biologically active substances with antiviral properties. Sixty products were tested for antiinfluenza virus activity in tissue cultures. The most effective products were further studied in fertile hen's eggs and in experimental influenza infection in mice.

\section{Materials and Methods}

\section{Substances}

The investigated marine algae and invertebrates were collected in the Black Sea in summer. The fresh organisms were cleaned from other organisms, immediately dipped in ethanol and transported to the laboratory. About $100-120 \mathrm{~g}$ of the fresh material, corresponding to $10-15 \mathrm{~g}$ of dry material, was homogenized with chloroform methanol (500 ml, 1:1, v/v) and refluxed for a few minutes in order to inactivate the enzymes. The extractions were repeated three times, the combined extracts were concentrated to about $200 \mathrm{ml}$ and $200 \mathrm{ml}$ water was added. Two layers were formed - the upper one - water (W) contains polar compounds, while the lower layer - chloroform, contains lipophilic compounds (L). The lipophilic layers contain about $1 \mathrm{~g}$ material, while the water layers contain about $2-3 \mathrm{~g}$ material. In some cases total $\mathrm{MeOH}$ extracts (about $3 \mathrm{~g}$ ), $n$ $\mathrm{BuOH}$ or $\mathrm{CH}_{3} \mathrm{Cl}$ extracts (about $1 \mathrm{~g}$ ) have been prepared by extraction of $100 \mathrm{~g}$ fresh material with $3 \times 400 \mathrm{ml}$ of the solvent $n$-butanol (see Table I). The most effective extracts (Ceramium rubrum, Phyllophora nervosa, Polysiphonia denudata) were subjected to further separation by consecutive extraction of the water extract $(150 \mathrm{mg}$ in water:ethanol 1:3, v/v $100 \mathrm{ml}$ ) with equal volumes of petroleum ether, dichloroethane, ethyl acetate and $n$-butanol. The most active product, water extract from Polysiphonia denudata (Rhodophyta) was subjected to chromatography with charcoal and eluted by $\mathrm{MeOH} / \mathrm{H}_{2} \mathrm{O}$ mixtures with increasing concentrations of $\mathrm{MeOH}$, pure $\mathrm{MeOH}$ and acetone:MeOH 2:1, v/v. The water extract was subjected to acidic hydrolysis with $5 \mathrm{ml} 15 \% \mathrm{HCl}$. After refluxing for two hours the reaction mixture was cooled and subsequently extracted with equal 
volumes of methylene chloride and $n$-butanol. For the antiviral experiments $10 \%$ stock solutions of the preparations were made in distilled sterile water and the working dilutions further were made in cell culture medium ex tempore.

\section{Viruses}

Avian influenza virus $\mathrm{A} /$ chicken/Germany/27, strain Weibridge (H7N7) (A/H7N7) and human influenza viruses - $\mathrm{A} / \mathrm{PR} / 8 / 34(\mathrm{H} 1 \mathrm{~N} 1)(\mathrm{A} / \mathrm{H} 1 \mathrm{~N} 1)$, A/Krasnodar/101/59 (H2N2) (A/H2N2), A/Hong Kong/1/68 (H3N2) (A/H3N2), B/Lee/40 were grown in tissue cultures of chorioallantoic membranes (CAM) or in fertile hen's eggs. A/Aichi/2/ $68(\mathrm{H} 3 \mathrm{~N} 2)$ had been adapted to the lung of white mice. The viruses were maintained by passages in 11 days old hen's fertile eggs and were used as allantoic fluids. The virus stock was stored at $70{ }^{\circ} \mathrm{C}$. The virus infectious titers were determined by hemagglutinin(HA) titration endpoint calculated according to Reed and Muench (1938) and expressed in $50 \%$ infectious doses per $\mathrm{ml}$ ( $\log$ $\left.\mathrm{ID}_{50} / \mathrm{ml}\right)$.

\section{Test systems}

The antiviral studies were carried out in the following test systems:

1. Roller cultures of CAM from 11-12 days old fertile hen's eggs were prepared a/ according to Zakstelskaya (1975) for toxicity and b/ according to Horvath (1954) for the antiviral experiments. The cultures were maintained in glass tubes on a roller apparatus. The culture medium contained $4 \%$ phosphate buffer, $4 \%$ glucose, $1 \%$ ovoalbumin and antibiotics $(100 \mu \mathrm{g} / \mathrm{ml}$ streptomycin and $100 \mathrm{U} / \mathrm{ml}$ penicillin $\mathrm{G}$ ).

2. Stationary cultures of CAM were prepared after Maltzeva et al. (1973). The culture medium was as described above.

3. 10-11 days old fertile hen's eggs. The eggs were kept at $37^{\circ} \mathrm{C}$.

4. White mice, strain ICR, male and female, 18 $20 \mathrm{~g}$.

\section{Toxicity}

In CAM the toxicity was monitored following the effect of the preparations on tissue morphology and viability. Roller CAM (1a) in glass tubes were cultivated in the presence of serial two-fold dilutions of the substances and checked daily for $72 \mathrm{~h}$ for morphological changes. The toxicity was scored (score $0=0 \%$ changed CAM, score $1=$ $0-25 \%$ changed CAM, score $2=25-50 \%$ changed CAM, score $3=50-75 \%$ changed CAM, score $4=75-100 \%$ changed CAM). The maximal tolerated concentration (MTC) was determined as the dose that caused no detectable morphological changes in CAM. The concentration required to cause visible changes in $50 \%$ of intact CAM with respect to control, $50 \%$ toxic concentration $\left(\mathrm{TC}_{50}\right)$, was evaluated from graphic plots. Fertile hen's eggs were inoculated with serial two-fold dilutions of the substances; early and late toxicity was estimated (Ilyenko, 1977). The toxicity for mice was determined according to Ilyenko (1977). $50 \%$ lethal dose $\left(\mathrm{LD}_{50}\right)$ was determined as the dose that caused death in $50 \%$ of intact fertile eggs and animals.

\section{Hemagglutination (HA) assay}

Fifty $\mu \mathrm{l}$ of allantoic virus suspensions were diluted 8 times, two-fold dilution each time, and incubated with an equal volume of $1 \%$ hen erythrocyte suspension for $30 \mathrm{~min}$ at the room temperature. The hemagglutination titre was estimated as the reciprocal value of the last dilution in which hemagglutination was observed.

\section{Virucidal activity}

The direct inactivating effect was tested in a contact assay. Ten-fold diluted allantoic fluids of the viruses were treated with equal volumes of two-fold serial dilutions of the substances for $1 \mathrm{~h}$ at $37^{\circ} \mathrm{C}$. The difference in the biological activities of the control and treated viruses was determined on the base of HA-production (HA assay).

\section{Antiviral assays}

In vitro and in ovo the virus-inhibitory effect was followed by the reduction of virus infectivity. In CAM a modification of EPTT ( $50 \%$ endpoint titration technique) described by Vanden Berghe et al. (1986) for cell cultures was used. In roller (1b) or stationary cultures of CAM serial ten-fold dilutions of the viruses $\left(1-10^{4} \mathrm{ID}_{50} / \mathrm{ml}\right)$ were inoculated simultaneously with two-fold dilutions of 
the preparations. The antiviral experiments lasted for $48 \mathrm{~h}(72 \mathrm{~h}$ for $\mathrm{B} /$ Lee $)$ at $37^{\circ} \mathrm{C}\left(33^{\circ} \mathrm{C}\right.$ for $\mathrm{B} /$ Lee). At the end of the incubation period the viral growth was evaluated by hemagglutination of the supernatants of the tissue cultures per se with $1 \%$ solution of hen's erythrocytes and the infectious titres were calculated. The minimal inhibitory concentration (MIC) was determined as the minimal dose that caused significant reduction of viral reproduction in CAM $\left(\delta \log \mathrm{ID}_{50} / \mathrm{ml}=1\right)$. The significance of the difference between infectious titres of control and treated viruses was estimated by Student's $t$ test. The dose that caused $0.5 \mathrm{log}$ $(50 \%)$ reduction of infectious titres, $50 \%$ effective concentration $\left(\mathrm{EC}_{50}\right)$, was estimated from graphic plots. The selectivity index (SI) was calculated from the ratio $\mathrm{TC}_{50} / \mathrm{EC}_{50}$.

In fertile eggs two-fold dilutions of the substances were inoculated $1 \mathrm{~h}$ before the addition of serial ten-fold dilutions of the viruses $\left(1-10^{4} \mathrm{ID}_{50} /\right.$ $\mathrm{ml})$. At the end of $48 \mathrm{~h}$ incubation the viral growth was estimated as described above for CAM. The antiviral effect of the preparations was determined by the differences in the virus infectious titres $(\delta$ $\left.\log \mathrm{ID}_{50} / \mathrm{ml}\right)$ in the absence and in the presence of the preparations.

In vivo the antiinfluenza effect was determined in white mice infected nasally with $1-10 \mathrm{LD}_{50}$ of A/Aichi (H3N2). The substances were inoculated according to a prophylactic-therapeutic schedule before and after infection $(-24,-2,+2,+24,+48$ h). The mortality rate was followed for 14 days. The inhibitory effect was determined on the basis of the reduction of mortality and the prolongation of survival times (Ilyenko, 1977). The protective index (PI) was determined from the equation $\mathrm{PI} \%=\mathrm{PR}-1 / \mathrm{PR}$, where $\mathrm{PR}=\mathrm{M}_{\text {control }} / \mathrm{M}_{\text {experiment }}$ and $\mathrm{M}$ is \% of mortality. The results are the mean values of 2-4 experiments.

The antiviral effect was scored with respect to the inhibition of the reproduction of one or more viral strains caused by the preparations applied in a 1/4 MTC dose as follows: score $-=$ non-significant inhibition, score $+=50 \%$ inhibition, score $++=90 \%$ inhibition, score $+++=99 \%$ inhibition, score $++++=>99 \%$ inhibition.

In all antiviral experiments non-drug treated, mock-infected cultures were used as tissue culture control and non-drug treated, virus-infected cultures - as virus control. Rimantadine hydrochlo- ride (Hoffmann - La Roche Inc., Nutley, NJ), $(1 \mu \mathrm{g} / \mathrm{ml})$ was used as a positive control.

\section{Results and Discussion}

Many natural products have been found to possess virus-inhibitory activity (Vanden Berghe et al., 1986). Recent biochemical and pharmacological investigations on marine organisms evaluate them as an interesting source of potential antiviral compounds (Cannell, 1993; Che, 1991; Molinski, 1993; Rinehart, 1989; Vozzinskaya et al. 1993; Witvrouw and De Clercq, 1997). The information about the antiinfluenza virus activity of marine products is scarce. Gerber et al. (1958) established a protective effect of seaweed extracts for chicken embryos infected with influenza B virus (but not influenza A). Kathan (1965) reported inhibitory effect on influenza virus neuraminidase for kelp extracts. A six-component antibiotic complex, isolated from Ulva lactuca reduced the infectivity of human influenza virus A/PR8 (Ivanova et al., 1991), some polysaccharides inhibited the reproduction of influenza viruses types A and B (Ivanova et al., 1994, Witvrouw and De Clercq, 1997). Antiinfluenza virus activity of marine microalgae (Michailov et al., 1994) and marine invertebrates has also been detected (Bichurina et al., 1993).

As a part of a project on the biological effects of marine products sixty extracts, fractions and synthetic compounds from marine organisms (sea plants and invertebrates) were tested for antiinfluenza virus activity (Table I). 24 of the products (40\%) showed a significant antiviral effect, among them 5 markedly inhibited viral reproduction and 2 exhibited notable activity. This result is a much higher figure than that, reported by Ballesteros et al. (1992) for a screening experiment of 65 preparations $(21 \%)$ and closer to the outcome of screening experiment of 73 extracts, reported by Premanathan et al. (1992) (50\%). Virus-inhibitory effect was found mainly among the water extracts - Cystoseira barbata (Heterocontophyta), Ulva rigida (Chlorophyta), Phyllophora nervosa (Rhodophyta), Ceramium rubrum (Rhodophyta) and Polysiphonia denudata (Rhodophyta). The lipophilic extracts from Gelidium latifolium and Polysiphonia denudata and two synthetic marine sponge alkaloids (aplysinopsine and its $\mathrm{N}$-methyl derivative) were also active. The virus-inhibitory effect 
Table I. Antiinfluenza virus effects of marine products.

\begin{tabular}{|c|c|c|c|c|c|}
\hline $\mathrm{N}$ & Marine organism & Preparation & $\begin{array}{l}\mathrm{MTC}^{\mathrm{a}} \\
{[\mathrm{mg} / \mathrm{ml}]}\end{array}$ & $\begin{array}{c}\mathrm{MIC}^{\mathrm{b}} \\
{[\mathrm{mg} / \mathrm{ml}]}\end{array}$ & $\begin{array}{l}\text { Antiviral } \\
\text { effect }\end{array}$ \\
\hline & Heterocontophyta - Phaeophycaceae & & & & \\
\hline 1 & Cystoseira barbata C. Agardh & lipophilic extract & 1.0 & 0.25 & + \\
\hline 2 & Cystoseira barbata & water extract & 5.0 & $1.0-2.0$ & ++ \\
\hline 3 & Cystoseira crinita (Desf.) Bory & lipophilic extract & 0.12 & $>0.12$ & - \\
\hline 4 & Cystoseira crinita & water extract & 0.5 & 0.25 & + \\
\hline \multirow[t]{2}{*}{5} & Punctaria plantaginea (Roth) Grev. & lipophilic extract & $>500$ & $>500$ & - \\
\hline & Chlorophyta - Cladophorophycaceae & & & & \\
\hline 6 & Chaetomorpha aerea (Dilwyn) Kutz & $\mathrm{MeOH}$ extract - I fr & 2.0 & $>2$ & - \\
\hline 7 & Chaetomorpha aerea & $\mathrm{MeOH}$ extract - II fr. & 2.0 & $>2$ & - \\
\hline 8 & Cladophora vagabunda (L.) Hoek & lipophilic extract & 3.3 & 0.8 & + \\
\hline \multirow[t]{2}{*}{9} & Cladophora vagabunda & water extract & 2.0 & $>2$ & - \\
\hline & Chlorophyta - Ulvophycaceae & & & & \\
\hline 10 & Ulva rigida $\mathrm{C}$. Agardh & lipophilic extract & 1.0 & $>1.0$ & - \\
\hline 11 & Ulva rigida & water extract & 10.0 & 0.7 & +++ \\
\hline 12 & Ulva rigida + Chaetomorpha aerea & $\mathrm{MeOH}$ extract - I fr. & 2.0 & 0.5 & + \\
\hline 13 & Ulva rigida + Chaetomorpha aerea & $\mathrm{MeOH}$ extract - II fr. & 2.0 & 0.5 & + \\
\hline \multirow[t]{2}{*}{14} & Ulva rigida + Chaetomorpha aerea & $\mathrm{MeOH}$ extract - III fr. & 2.0 & 0.5 & + \\
\hline & Rhodophyta - Bangiophycaceae & & & & \\
\hline \multirow[t]{2}{*}{15} & Bangia fuscopurpurea (Dillwyn) (Yutz.) & lipophilic extract & 0.15 & $>0.1$ & - \\
\hline & Rhodophyta - Florideophycaceae & & & & \\
\hline 17 & Ceramium rubrum (Huds.) Ag. & lipophilic extract & 5.0 & $>5$ & - \\
\hline 18 & Ceramium rubrum & water extract & 10.0 & $0.12-1.0$ & +++ \\
\hline \multirow[t]{2}{*}{19} & Ceramium rubrum & $\mathrm{CH}_{3} \mathrm{Cl}$ & 0.3 & 0.05 & + \\
\hline & Fractionation of $C$. rubrum (W) & & & & \\
\hline 20 & -“- & petroleum ether fr. & 0.1 & $>0.1$ & + \\
\hline 21 & -" - & dichloroethane fr. & 0.1 & $>0.1$ & - \\
\hline 22 & -“- & ethylacetic fr. & 0.1 & $>0.1$ & - \\
\hline 23 & -“- & $n$-butanol fr. & 0.1 & $>0.1$ & - \\
\hline 24 & -“- & $\mathrm{H}_{2} \mathrm{O}$ residue & 0.1 & $>0.1$ & - \\
\hline 25 & Corallina officinalis Linnaeus & lipophilic extract & 1.0 & $>1$ & - \\
\hline 26 & Corallina officinalis & water extract & 10.0 & 2.5 & + \\
\hline 27 & Gelidium latifolium (Grev.) Born et Thur. & lipophilic extract & 10.0 & 0.25 & ++ \\
\hline 28 & Gelidium latifolium & water extract & 10.0 & 2.5 & + \\
\hline 29 & Polysiphonia denudata (Dillwyn) Kutz. & lipophilic extract & 8.0 & $0.5-1.6$ & ++ \\
\hline 30 & Polysiphonia denudata & water extract & 10.0 & $0.03-0.25$ & ++++ \\
\hline \multirow[t]{2}{*}{31} & Polysiphonia denudata & $\mathrm{BuOH}$ extract & 0.5 & $>0.5$ & - \\
\hline & Fractionation of $P$. denudata $(\mathrm{W})$ & & & & \\
\hline 32 & -“- & petroleum ether fr. & 0.1 & $>0.1$ & - \\
\hline 33 & -“- & dichloroethane fr. & 0.1 & $>0.1$ & - \\
\hline 34 & -“- & ethylacetic fr. & 0.1 & 0.02 & ++ \\
\hline 35 & -“- & $n$-butanol fr. & 0.1 & $>0.1$ & - \\
\hline \multirow[t]{2}{*}{36} & -“- & $\mathrm{H}_{2} \mathrm{O}$ residue & 0.1 & $>0.1$ & - \\
\hline & $\begin{array}{l}\text { Chromatography on charcoal of } P \text {. denud } \\
\text { (W) }\end{array}$ & & & & \\
\hline 37 & -" - & $\mathrm{H}_{2} 0: \mathrm{MeOH} 9: 1$ & 0.01 & $>0.01$ & - \\
\hline 38 & -“- & $\mathrm{H}_{2} 0: \mathrm{MeOH} 1: 1$ & 0.2 & 0.05 & ++ \\
\hline 39 & -“- & $\mathrm{MeOH}$ & 0.1 & $>0.1$ & - \\
\hline \multirow[t]{2}{*}{40} & $-“-$ & acetone:MeOH 2:1 & 0.2 & $>0.2$ & - \\
\hline & Acidic hydrolysis of $P$. denudata $(\mathrm{W})$ & & & & \\
\hline 41 & -“- & $\left(\mathrm{CH}_{2} \mathrm{Cl}\right)_{2}$ & 1.0 & $>1$ & - \\
\hline 43 & $-“-$ & $\mathrm{H}_{2} \mathrm{O}$ residue & 1.0 & $>1$ & - \\
\hline 44 & Phyllophora nervosa (DC.) Grev. & lipophilic extract & 1.0 & 0.25 & + \\
\hline 45 & Phyllophora nervosa & water extract & 10.0 & $0.25-1.8$ & +++ \\
\hline
\end{tabular}


Table I. (cont).

\begin{tabular}{|c|c|c|c|c|c|}
\hline $\mathrm{N}$ & Marine organism & Preparation & $\begin{array}{c}\mathrm{MTC}^{\mathrm{a}} \\
{[\mathrm{mg} / \mathrm{ml}]}\end{array}$ & $\begin{array}{c}\mathrm{MIC}^{\mathrm{b}} \\
{[\mathrm{mg} / \mathrm{ml}]}\end{array}$ & $\begin{array}{c}\text { Antiviral } \\
\text { effect }\end{array}$ \\
\hline & \multicolumn{5}{|l|}{ Fractionation of $P$. nervosa $(\mathrm{W})$} \\
\hline 46 & -“- & petroleum ether fr. & 0.1 & $>0.1$ & - \\
\hline 47 & -“- & dichloroethane fr. & 0.1 & $>0.1$ & - \\
\hline 48 & -“- & ethylacetic fr. & 0.1 & $>0.1$ & - \\
\hline 49 & $-“-$ & $n$-butanol fr. & 0.1 & $>0.1$ & - \\
\hline \multirow[t]{2}{*}{50} & $-“-$ & residue & 0.1 & $>0.1$ & - \\
\hline & \multicolumn{5}{|l|}{ Marine invertebrates } \\
\hline 51 & Botryllus schlosseri (Tunicate) & lipophilic extract & 0.5 & $>0.5$ & - \\
\hline 52 & Botryllus schlosseri & water extract & 0.5 & 0.03 & ++ \\
\hline 53 & Dysidea fragilis (Sponge) & lipophilic extract & 0.02 & $>0.02$ & - \\
\hline 54 & Dysidea fragilis & $\mathrm{CH}_{3} \mathrm{Cl}$ extract & 0.02 & $>0.02$ & - \\
\hline 55 & Dysidea fragilis & $\mathrm{MeOH}$ extract & 0.2 & $>0.2$ & - \\
\hline 56 & Dysidea fragilis & water extract & 0.2 & $>0.2$ & - \\
\hline 57 & Synthetic sponge alkaloid & aplysinopsin & 0.01 & 0.002 & ++ \\
\hline 58 & Synthetic sponge alkaloid & $\mathrm{N}$-methyl aplysinopsin & 0.01 & 0.002 & ++ \\
\hline 59 & Synthetic sponge alkaloid & desmethyl aplysinopsin & 0.01 & $>0.01$ & - \\
\hline 60 & Rapana thomasiana (Snail) & water extract & 0.12 & $>0.12$ & - \\
\hline
\end{tabular}

${ }^{a}$ Maximal tolerated concentration, the dose that caused no detectable morphological changes in intact CAM.

${ }^{\mathrm{b}}$ Minimal inhibitory, the minimal dose that caused significant reduction of viral reproduction in CAM.

was dose-dependent (Tables I, II). The strain-specificity of the virus-inhibitory effect (Table II) was consistent with its selectivity. The toxicity of the active extracts varied and their selectivity index $\left(\mathrm{SI}=\mathrm{TC}_{50} / \mathrm{EC}_{50}\right)$ was between 5 to 403 . The active preparations did not exhibit any direct virus-inactivating activity when applied in doses up to $5 \mathrm{mg} / \mathrm{ml}$.

The same algae extracts were tested for antimicrobial activity (Serkedjieva et al., 1998); it was shown that some of them reduced the growth of St. aureus and B. subtilis, but there was limited coincidence between the antiviral and antimicrobial activities. Lack of direct virus-inactivating and antimicrobial activities in the effective preparations suggested that the virus-inhibitory effect was specific.

Further the most active extracts Ceramium rubrum (W), Polysiphonia denudata (W) and Phyllophora nervosa $(\mathrm{W})$ were fractionated with solvents

Table II. Drug susceptibility of influenza viruses to marine products.

\begin{tabular}{|c|c|c|c|c|c|c|c|c|c|c|c|c|}
\hline \multirow[t]{2}{*}{$\mathrm{N}$} & \multirow{2}{*}{$\begin{array}{l}\text { Marine organism } \\
\text { (Preparation) }\end{array}$} & \multirow[b]{2}{*}{$\begin{array}{c}\mathrm{TC}_{50}{ }^{\mathrm{a}} \\
{[\mathrm{mg} / \mathrm{ml}]}\end{array}$} & \multicolumn{2}{|c|}{$\mathrm{A} / \mathrm{H} 7 \mathrm{~N} 7$} & \multicolumn{2}{|c|}{$\mathrm{A} / \mathrm{H} 1 \mathrm{~N} 1$} & \multicolumn{2}{|c|}{$\mathrm{A} / \mathrm{H} 2 \mathrm{~N} 2$} & \multicolumn{2}{|c|}{$\mathrm{A} / \mathrm{H} 3 \mathrm{~N} 2$} & \multicolumn{2}{|c|}{ B/Lee } \\
\hline & & & $\begin{array}{l}\mathrm{EC}_{50}{ }^{\mathrm{b}} \\
{[\mathrm{mg} / \mathrm{ml}]}\end{array}$ & $\begin{array}{c}\delta \log \\
\mathrm{ID}_{50} / \mathrm{ml}^{\mathrm{c}}\end{array}$ & $\begin{array}{c}\mathrm{EC}_{50}{ }^{\mathrm{b}} \\
{[\mathrm{mg} / \mathrm{ml}]}\end{array}$ & $\begin{array}{c}\delta \log \\
\mathrm{ID}_{50} / \mathrm{ml}^{\mathrm{c}}\end{array}$ & $\begin{array}{l}\mathrm{EC}_{50}{ }^{\mathrm{b}} \\
{[\mathrm{mg} / \mathrm{ml}]}\end{array}$ & $\begin{array}{c}\delta \log \\
\mathrm{ID}_{50} / \mathrm{ml}^{\mathrm{c}}\end{array}$ & $\begin{array}{c}\mathrm{EC}_{50} \mathrm{~b} \\
{[\mathrm{mg} / \mathrm{ml}]}\end{array}$ & $\begin{array}{c}\delta \log \\
\mathrm{ID}_{50} / \mathrm{ml}^{\mathrm{c}}\end{array}$ & $\begin{array}{c}\mathrm{EC}_{50}{ }^{\mathrm{b}} \\
{[\mathrm{mg} / \mathrm{ml}]}\end{array}$ & $\begin{array}{c}\delta \log \\
\mathrm{ID}_{50} / \mathrm{ml}^{\mathrm{c}}\end{array}$ \\
\hline 2 & Cystoseira barbata (W) & 5.6 & n.d. & & 1.2 & 2.1 & 1.1 & 1.67 & 1.6 & 2.33 & 2.0 & n.s. \\
\hline 10 & Ulva rigida $(\mathrm{W})$ & 10.5 & n.d. & & 0.5 & 2.23 & 0.4 & 1.4 & 0.5 & 2.67 & 0.5 & 1.6 \\
\hline 18 & Ceramium rubrum $(\mathrm{W})$ & 10.2 & 0.12 & 2.3 & 0.5 & 1.5 & 0.25 & 1.6 & 0.12 & 2.6 & 1.1 & 1.5 \\
\hline 27 & Gelidium latifolium (L) & 10.1 & n.d. & & 0.25 & 1.63 & 0.25 & n.s. & 0.25 & 1.8 & 0.25 & n.s. \\
\hline 29 & Polysiphonia denudata (L) & 8.2 & 0.5 & 2.5 & 0.5 & 1.5 & 1.4 & n.s. & 0.25 & 1.6 & 1.6 & n.s. \\
\hline 30 & Polysiphonia denudata (W) & 12.1 & 0.1 & 2.8 & 0.12 & 3.23 & 0.25 & 1.5 & 0.03 & 3.67 & 1.3 & 2.1 \\
\hline 45 & Phyllophora nervosa (W) & 10.8 & 0.8 & 1.2 & 0.25 & 2.5 & 1.8 & 2.33 & 0.25 & 2.8 & 0.25 & 2.33 \\
\hline 57 & Aplysinopsin & 0.01 & n.d & & 0.002 & 3.5 & n.d & & 0.002 & 2.67 & 0.002 & 3.23 \\
\hline 58 & N-Methyl aplysinopsin & 0.01 & n.d & & 0.01 & 1.8 & n.d & & 0.01 & 1.6 & 0.01 & 2.0 \\
\hline
\end{tabular}

a $50 \%$ toxic concentration, the dose required to cause visible changes in $50 \%$ of intact cultures.

b $50 \%$ effective concentration, the dose that caused $0.5 \log (50 \%)$ reduction of infectious titres.

${ }^{c}$ Inhibition exhibited by the preparations in a $1 / 4 \mathrm{LD}_{50}$ dose.

n.s. - not significant $(\mathrm{P}<0.05)$.

n.d. - not determined.

W: Water phase.

L: Lipophilie phase, see Materials and Methods. 
of increasing polarity. Only the ethyl acetate and water/methanol fractions of Polysiphonia denudata $(\mathrm{W})$ reduced significantly influenza virus replication (Table I).

The water extracts from Polysiphonia denudata, Cystoseira barbata, Ulva rigida, Phyllophora nervosa and Ceramium rubrum inhibited significantly the reproduction of influenza virus also in fertile eggs (Table III). The water extracts from Polysiphonia denudata and Ulva rigida reduced the mortality rate of white mice in experimental influenza infection with A/Aichi (H3N2) when applied orally and extended the time of survival (Table IV). The inhibitory effect of the aqueous extract from Polysiphonia denudata was further studied in detail. The preparation reduced selectively and in a dose-related manner the virus-induced cytopathic effect, the infectious virus yields, the expression of viral proteins on the infected cell surface in ELISA, the virus-specific protein synthesis in chicken embryo fibroblast cells, infected with A/FPV (H7N1) (unpubl.).

The presented results do not offer an explanation about the mode of the inhibitory activity of the extracts from marine organisms. There are data that many marine bioactive products have affinities for certain cellular receptors in the mammalian cell (Molinski, 1993) and thus can interfere with the initial steps of viral replication. Ehresmann et al., 1997 suggested that herpes virus inhibition by algal extracts was due to a block at viral adsorption. An algal extract inhibited herpes virus penetration in a dose-dependent manner, did not inhibit virus attachment to cells and did not affect host protein synthesis (Hayashi et al., 1993). We have studied in detail the virus-inhibitory effect of the water extract from Polysiphonia denudata and it was found that the preparation reduced the reproduction of $\mathrm{A} / \mathrm{H} 3 \mathrm{~N} 2$ by inhibition of viral adsorption to susceptible cells and had an effect on viral synthetic stages (unpubl.).

At this stage of our investigations we can not define the biologically active components in the extracts. However the presented results support the view that marine organisms are an interesting source of potential antiviral compounds (Cannell, 1993; Che, 1991; Rinehart, 1989; Vozzinskaya et al. 1993; Witvrouw and De Clercq, 1997). Projects on

Table III. Inhibitory effect of effective marine products on the reproduction of influenza virus in embryonated hen's eggs.

\begin{tabular}{|c|c|c|c|c|}
\hline $\mathrm{N}$ & Marine organism (Preparation) & $\mathrm{LD}_{50}{ }^{\mathrm{a}}[\mathrm{mg} / \mathrm{ml}]$ & $\begin{array}{c}\mathrm{A} / \mathrm{H} 1 \mathrm{~N} 1 \\
\delta \log \mathrm{ID}_{50} / \mathrm{ml}^{\mathrm{b}}\end{array}$ & $\begin{array}{c}\mathrm{A} / \mathrm{H} 3 \mathrm{~N} 2 \\
\delta \log \mathrm{ID}_{50} / \mathrm{ml}^{\mathrm{b}}\end{array}$ \\
\hline 2 & Cystoseira barbata (W) & 12.2 & n.s. & 1.17 \\
\hline 10 & Ulva rigida $(\mathrm{W})$ & 10.1 & 1.87 & 2.67 \\
\hline 18 & Ceramium rubrum $(\mathrm{W})$ & 12.4 & 2.1 & 2.33 \\
\hline 30 & Polysiphonia denudata (W) & 16.2 & 2.37 & 2.77 \\
\hline 45 & Phyllophora nervosa (W) & 12.0 & 1.25 & 1.63 \\
\hline
\end{tabular}

a $50 \%$ lethal dose, the dose that caused death in $50 \%$ of intact embryonated eggs.

${ }^{b}$ Inhibition exhibited by the preparations in a $1 / 4 \mathrm{LD}_{50}$ dose.

* Not significant $(\mathrm{P}<0.05)$.

Table IV. Protective effect of marine algae extracts on experimental influenza infection in mice.

\begin{tabular}{lllcrrr}
\hline $\mathrm{N}$ & Marine organism (Preparation)\# & Inoculation & $\begin{array}{c}\mathrm{LD}_{50}{ }^{\mathrm{a}} \\
{[\mathrm{g} / \mathrm{kg}]}\end{array}$ & $\begin{array}{c}\text { Dosage } \\
{[\mathrm{g} / \mathrm{kg}]}\end{array}$ & $\begin{array}{c}\mathrm{PI}^{\mathrm{c}} \\
\%\end{array}$ & $\begin{array}{c}\mathrm{MST}^{\mathrm{d}} \\
{[\mathrm{days}]}\end{array}$ \\
\hline 10 & Ulva rigida $(\mathrm{W})$ & oral & $>10.0$ & 1.0 & 46.1 & +2.6 \\
30 & Polysiphonia denudata $(\mathrm{W})$ & oral & $>10.0$ & 1.0 & 63.7 & +4.8 \\
\hline
\end{tabular}

a $50 \%$ lethal dose, the dose that caused death in $50 \%$ of intact animals.

b The indicated dose $x 5$.

c Protective index $=$ PR-1/PR, where PR (protective ratio) $=\mathrm{M}_{\text {control }} / \mathrm{M}_{\text {experiment }}$, and $\mathrm{M}$ is $\%$ of mortality (Ilyenko, 1977).

d Mean survival time.

\# Application according to the schedule $-24,-2,+2,+24,+48 \mathrm{~h}$ with respect to viral infection. 
the virus - inhibitory activity start with a screening of extracts (Ballesteros et al., 1992; Ehresmann et al., 1997; Premanathan et al., 1992), followed by the isolation of biologically active substances. Some of the constituents of marine algae, such as carageenans and alginates have no analogues (Vozzinskayaa et al., 1993). Sulfated polysaccharides attracted considerable attention as potential antiviral agents (for review see Witvrouw and De Clercq, 1997).
In conclusion it can be stated that the Bulgarian Black Sea coast offers marine plants and invertebrates possessing pronounced antiviral activity. The study of their biologically active constituents is in progress.

\section{Acknowledgements}

The present studies were supported by research grants N 535 from The Ministry of Higher Education and N X-443 and X-710 from The National Science Fund, Sofia.
Ballesteros E., Martin D. and Uriz M. J. (1992), Biological activity of extracts from some Mediterranean macrophytes. Bot. Marina 35, 481-485.

Bichurina M. A., Nikitina L. E. and Sovetova M. G. (1993), Virus-inhibitory activity of a preparation from mussels. Voprosi virusologii 3, 134-136 (in Russian).

Cannell R. J. P. (1993), Algae as a source of biologically active products. Pestic. Sci. 39, 147-153.

Che C. T. (1991), Marine products as a source of antiviral drug leads. Drug Dev. Res. 23, 201-218

Ehresmann D. W., Deig E. F., Hatch M. T., DiSalvo L. H. and Vedros N. A. (1977), Antiviral substances from Californian marine algae. J. Phycol. 13, 37-40.

Gerber P., Dutcher D. D., Adams E. V. and Sherman J.H. (1958), Protective effect of seaweed extracts for chicken embryos infected with influenza B or mumps virus. Proc. Soc. Exp. Biol. Med. 99, 590-593.

Hayashi K., Hayashi T. and Morita N. (1993), An extract from Spirulina pratensis is a selective inhibitor of HSV type 1 penetration into HeLa cells. Phytother. Res. 7, $76-80$.

Horvath J. (1954), A new sensitive method of the rolling drum type for influenza titration. Acta Microbiol. Acad. Sci. Hung. 1, 481-494.

Ilyenko V. I. (1977), In: Methods for the Evaluation of the Antiinfluenza Activity of Chemical Compounds, Ministry of Health, Leningrad, pp. 3-34 (in Russian).

Ivanova V., Rouseva R., Kolarova M., Serkedjieva J., Rachev R. and Manolova N. (1994), Isolation of a polysaccharide with antiviral effect from Ulva lactuca. Prep. Biochem. 24, 83-97.

Ivanova V., Gegova G., Manolova N., Serkedjieva J. and Belomajova D. (1991), Biologically active substances from marine organisms. I. Isolation of a substance from marine algae with antiviral effect. Herba Hungarica 30, 47-53.

Kathan R. U. (1965), Kelp extracts as antiviral substances. Ann. NY Acad. Sci. 130, 390-397.
Maltzeva A. I., Agranovskaya E. I., Zelichenok J. M. and Schwarzman Ya. S. (1973), The reproduction of influenza viruses in chorioallantoic membranes from hens' embryonated eggs. Laboratornoe delo 11, 689690 (in Russian).

Michailov J., Dilov H., Gagov I. and Popov G. (1994), Antiviral effect of a preparation from microalgae extract. C R Bulg. Acad. Sci. 47, 53-56.

Molinski T. F. (1993), Developments in marine natural products. Receptor-specific bioactive componds. J. Nat Prod. 56, $1-8$.

Premanathan M., Chandra K., Bajpai S. K. and Kathiresan K. (1992), A survey of some Indian marine plants for antiviral activity. Bot. Marina 35, 321-324.

Reed L. J. and Muench H. (1938), A simple method of estimating fifty per cent endpoints. Amer. J. Hyg. 27, $493-497$.

Rinehart K. L. (1989), Biologically active marine natural products. Pure Appl. Chem. 61, 525-528.

Serkedjieva J., Kujumgiev A., Ivanova V. and Popov S. (1998), Antiinfective activity of marine algae. In: Proc. IX Congress of Microbiology, Oct. 1998, Sofia, Bulgaria, pp. 234-237.

Vanden Berghe D. A., Vlietinck A. J. and Van Hoof L. (1986), Plant products as potential antiviral agents. Bull. Inst. Pasteur 84, 101-147.

Vozzinskaya V. B., Lucina N. P. and Maximova O. B. (1993), The prospects for using marine algae. Izvestiya Academii Nauk USSR 4, 592-599 (in Russian).

Witvrouw M. and De Clercq E. (1997), Sulfated polysaccharides extracted from sea algae as potential antiviral agents. Gen. Pharmacol. 29, 497-511.

Zakstelskaya L. J. (1975), Application of a neutralisation assay for the evaluation of antibodies to influenza virus A/Asia/57. Voprosi virusologii 6, 373-375 (in Russian). 